\title{
THROWING A TREE
}

\section{NEW FOREST}

THE two executioners stalk along over the knolls,

Bearing two axes with heavy heads shining and wide,

And a long limp two-handled saw toothed for cutting great boles, And so they approach the proud tree that bears the death-mark on its side.

Jackets doffed they swing axes and chop away just above ground, And the chips fly about and lie white on the moss and fallen leaves;

Till a broad deep gash in the bark is hewn all the way round, And one of them tries to hook upward a rope, which at last he achieves.

The saw then begins, till the top of the tall giant shivers:

The shivers are seen to grow greater each cut than before:

They edge out the saw, tug the rope; but the tree only quivers, And kneeling and sawing again, they step back to try pulling once more.

Then, lastly, the living mast sways, further sways: with a shout Job and Ike rush aside. Reached the end of its long staying powers The tree crashes downward: it shakes all its neighbours throughout, And two hundred years' steady growth has been ended in less than two hours. 